\title{
PI3HE
}

UDC 621.791 .3

M. M. Voron, PhD. (Engin.), Senior Research Scientist;

e-mail: mihail.voron@gmail.com

M. A. Fon Pruss, Postgraduate, Leading Engineer,

O. Ye. Byba, Engineer

Physico-Technological Institute of Metals and Alloys of the NAS of Ukraine

\section{MICROALLOYING AND MODIFICATION OF CAST ALUMINUM ALLOYS FOR INCREASING THEIR LEVEL OF EXPLOITATION PROPERTIES AT ELEVATED TEMPERATURES. A REVIEW}

The work is devoted to the analysis of the most effective microalloying additives and modifiers influence on increasing the mechanical properties of Al-Si-based alloys (silumins) during their operation at elevated temperatures. It is shown that cast aluminum alloys based on the Al-Si system belong to a number of cheap and widely used heat-resistant aluminum alloys, but their level of mechanical properties is quite low, and operating temperature limits are mostly determined by $250^{\circ} \mathrm{C}$. Modification and microalloying is widely used to increase the level of operational properties of this type of alloys. In recent years, complex multicomponent modification of silumins by such elements as chromium, manganese, nickel, cobalt, titanium, zirconium and vanadium is considered to be more and more effective in strengthening, grain refinement, shape shifting of iron-containing phases, etc. Triple addition of these elements in a total amount up to $0.25 \mathrm{wt}$. \% in many cases increases the efficiency of modification, compared with the addition of a single element. It is shown, that the addition of vanadium, molybdenum and tungsten helps to increase the hardness of alloys in the cast state. In this case, after hardening and two-stage aging, for alloys with molybdenum there is an increase in yield strength by $10 \%$ while maintaining the level of strength. Hafnium is considered as a promising nucleating element, the addition of which also significantly increases the resistance of recrystallization. Its addition to heat-resistant aluminum alloys can provide stabilization of mechanical properties up to $400^{\circ} \mathrm{C}$. It is necessary to ensure the maximum possible grinding of hafnium intermetallics, especially in the presence of silicon in the alloy. Modification of aluminum alloys with scandium with the addition of titanium, zirconium or hafnium promotes the formation of $\mathrm{Al}_{3}(\mathrm{Sc}, \mathrm{Zr} / \mathrm{Ti} / \mathrm{Hf})$ dispersoids with a cubic crystal lattice of favorable symmetry $\mathrm{L}_{2}$ and a stable layered "core-shell» structure. The content of silicon in the alloy should be minimal due to the formation of harmful silicides. The addition of rare earth metals has a similar effect, but without the formation of layered structures. In this case, REM can form silicides, and can modify eutectic or primary silicon. In both cases, the addition of transition metals or REM, simultaneously with the modification of scandium alloys, increases the high-temperature stability of cast Al-Si-based aluminum alloys mechanical properties of through the formation of less active and diffusion-moving reinforcing dispersed phases.

Keywords: cast aluminum alloys, silumins, complex modification, transition metals, rare earth metals. 


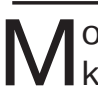
odification and microalloying of aluminum alloys, especially foundry ones, is a wellknown way to improve their quality and mechanical properties due to the impact on the structural-phase state [1, 2]. The most widely used industrial additives and modifiers for grain refinement and alloy strengthening are $\mathrm{Ti}_{1} \mathrm{TiB}_{2}, \mathrm{Zr}$, Sr, Sc, less often - V, Mo, $\mathrm{Hf}$ and REM [3, 4]. In addition to these elements, some other transition metals play an important role, which can perform several functions simultaneously - to be strongly soluble and insoluble dispersoid hardeners, to modify the structural components and change the morphology of the phases, etc. These mainly include $\mathrm{Fe}, \mathrm{Cr}, \mathrm{Mn}, \mathrm{Co}$, and $\mathrm{Ni}$ [5]. However, they are often considered as components of alloys, without taking into account the full range of possibilities and the simultaneous influence of several elements.

The role of these listed components in the formation of a structural-phase condition, mechanical and operational properties of foundry aluminum alloys is very important, and especially Al-Si-based alloys (silumins), as the most widely used, but those that have a fairly low set of mechanical properties. This is especially important for alloys that are contaminated with harmful impurities during repeated recycling [6].

Al-Si-based alloys make up the largest share (about $85-90 \%$ ) of cast aluminum alloys, mainly cause of they are technological and cheap. The automotive industry uses these alloys in plenty of products, including parts of internal combustion engines. Some of these alloys are creep-resistant with the ability to work at temperatures not exceeding $250{ }^{\circ} \mathrm{C}$. They also have quite high lavels of mechanical characteristics under operating conditions at these temperatures $\left(\sigma_{\mathrm{B}} \sim 150 \ldots 250 \mathrm{MPa}, \delta \sim 1-2 \%\right)$ as for this class of materials. The presence of silicon crystals in the eutectic of silumins provide heat and creep resistance to the alloy, and high strength values are provided by the solid-soluble hardening of the aluminum matrix, the effect of which may be higher with additional alloying by copper, magnesium, and manganese [6, 7].

Alloys of the $\mathrm{Al}-\mathrm{Si}$ and $\mathrm{Al}-\mathrm{Si}-\mathrm{Cu}$ systems lose strength with increasing temperature, which is explains a correspondingly sharp increase in the silicon diffusion coefficient. Along with this, silicon significantly reduces the positive effect of $\mathrm{Ti}, \mathrm{Zr}, \mathrm{Cr}, \mathrm{Mn}$, and some other elements capable of forming stable dispersoids of the intermetallic type, which increase the creep resistance of aluminum alloys $[6,8]$.

The main chemical additives for most aluminum alloys, including also silumines, are titanium, zirconium, and scandium [3, 4, 9]. If titanium and zirconium are grain refining additives, scandium acts as a strengthening agent, which forms a dispersoid, coherent to the aluminum matrix with a cubic lattice of symmetry $L 1_{2}$ [3]. Despite the positive effect of scandium on the creep resistance of aluminum alloys, it is a scarce and expensive element, so its use stays limited. More common elements, which are widely used for grinding the structure of cast aluminum alloys - $\mathrm{Ti}, \mathrm{Zr}$, $\mathrm{V}$, sometimes $\mathrm{Hf}$ and $\mathrm{Mo}$, are able to form in aluminum alloys separation with structures of tetragonal symmetry $\mathrm{DO}_{22}$ and $\mathrm{DO}_{23}$. In this case, adding $\mathrm{Cr}$, $\mathrm{Mn}, \mathrm{Fe}, \mathrm{Co}, \mathrm{Ni}, \mathrm{Cu}$, and $\mathrm{Zn}$ can be reduced the tetragonality of the lattice [10]. The stability of the tetragonal structure increases with an increasing atomic number of the element [11].

Titanium, vanadium and zirconium have low diffusion activity in aluminum and form stable intermetallics, so they provide a significant increase in the strength of aluminum alloys at operating temperatures up to $350{ }^{\circ} \mathrm{C}$ [12-14]. For A356 (AK7), A380 (AK8M3), and similar alloys, the total addition of these elements usually does not exceed $0.25 \mathrm{wt}$. $\%$ [15]. In the case of increasing their total content to $1 \mathrm{wt}$. \% $(0.56,0.2$ and $0.32 \mathrm{wt}$. \% of $\mathrm{Zr}$, Ti, and $\mathrm{V}$, respectively) in alloy $\mathrm{A} 380$ the formation of $\mathrm{Al}(\mathrm{Zr}, \mathrm{Ti}, \mathrm{V}) \mathrm{Si}$ compounds of lamellar form is observed, as well as the changes in morphology of eutectic components into flake and fibrous. This increases the strength (by 20\%) and ductility (by $\sim 40 \%$ ) of the alloy in the cast state at room temperature $\left(\sigma_{\mathrm{B}}=252 \mathrm{MPa}, \delta=4 \%\right)$. The strength at 200 and $300{ }^{\circ} \mathrm{C}$ differs little and is 217 and $187 \mathrm{MPa}$, respectively, which indicates the stabilization of mechanical properties due to structural and phase changes that occurred after modification [12]. An important condition for achieving this effect was to ensure very rapid crystallization of the metal. 
In $[5,16,17]$ it is noted that the addition to the A356 alloy of such elements as $\mathrm{Ni}$, $\mathrm{Cu}, \mathrm{Cr}$, Mo, V, and $\mathrm{W}$ under the conditions of mold casting and die casting contributed to improving the mechanical properties of castings both in the cast state and after heat treatment T6. It is shown, that the addition of $\mathrm{Cr}, \mathrm{Mo}, \mathrm{V}$, and $\mathrm{W}$ in amounts of $0.1-0.5 \mathrm{wt}$. \% significantly increases the hardness of the alloys in direct proportion to the concentration of additives. At the same time, under the influence of these elements on strength, there is an inverse relationship. The optimum is the content of the above modifying elements at a level of about 0.1 wt. \%.

In $[18,19]$, the separate effect of vanadium on the structural-phase state and properties of silumins have a temperate grinding grain effect and reduces the harmful effects of iron presence. The availability of $0.25 \mathrm{wt}$. \% vanadium in the alloy leads to a significant increase in the degree of alloying of the solid solution based on aluminum with silicon almost twice. The refinement of eutectic components due to the addition of vanadium, and the iron-containing phases instead of the needle form become branched with small sizes are also observed. With the increasing rate of crystallization of the melt, the modifying effect increases by analogy with the influence of other modifiers. The increase in creep resistance of silumins due to the addition of vanadium has been little studied, however analyzing the available studies, we can say that it is indirect.

The addition of chromium to Al-Si-based alloys is usually limited to $0.35 \mathrm{wt}$. \%, and gives them mainly structural stability and increasing the recrystallization temperature, which, in turn, means increasing the level of creep resistance [20,21]. Similar to manganese, chromium changes the needle morphology of harmful iron-containing phases to a more branched one, but its negative effect on the liquid fluidity of the metal is one and a half times greater than that only of manganese [22-24].

Cobalt, just like chromium, also can enhance the action of manganese in modifying harmful iron-containing phases. Note that it can form iron-containing phases of compact form without the presence of manganese in the alloy [23].

Molybdenum as a modifier for creep-resistant silumins has recently become increasingly popular and widely studied. In $[25,26]$ it noted that $0.1-0.3 \mathrm{wt}$. \% is the optimal amount for modification of silumins such as A356 and A380 that can be considered by molybdenum. In the cast state, the addition of molybdenum promotes the formation of the Al-Si-Mo and Al-Si-Fe-Mo system complex phases, which have a polygonal or starlike shape. The modified samples have pronounced gas and interdendritic porosity. The mechanical properties of such castings are slightly lower than similar ones obtained from unmodified alloy.

To obtain fine molybdenum-containing precipitates, multistage heat treatment, consisting of hardening and two-stage aging at $495^{\circ} \mathrm{C}$ and $540{ }^{\circ} \mathrm{C}$ for 6 hours and 1 hour, respectively is needed. This increases the yield strength of the alloy by $10 \%$ compared to the unmodified alloy. In this case, the tensile strength, which is more sensitive to the magnitude of the defects, remains almost the same neither at room temperature nor at elevated temperatures of $250^{\circ} \mathrm{C}[26,27]$.

Hafnium is another almost unexplored and promising modifier that increases the heat resistance and mechanical properties of aluminum alloys [28, 29]. The interest in the use of this element as a modifying admixture is mainly explained by the provision of the most effective recrystallization resistance and the possibility of forming of fine-crystalline dispersoids in the structure with very low diffusion activity and tetragonal FCC lattice. Like zirconium and titanium, hafnium has a peritectic-type diagram with aluminum, so it could be a similar grain-refining modifier.

In [30] under the conditions of repeated annealing, hardening, and forging of cast samples, the size of $\mathrm{Al}_{3} \mathrm{Hf}$ dispersoids in $\mathrm{Al}-0.95 \mathrm{Hf}$ alloy can reach $15 \mathrm{~nm}$, and they can be coherent to the aluminum matrix at such sizes. In the presence of silicon in the alloy at the level of $0.15 \%$ of the mass and above, the release, rate of dispersed intermetallic 
particles and their size increase. In the presence of silicon in the alloy at the level of 0.15 wt. \% and above, the rate of excretion of dispersed intermetallic particles and their size increase. At the same time, Al-Hf-Si intermetallics provide better preservation of hardness at high temperatures and more effectively suppress recrystallization processes up to temperatures of $400-450^{\circ} \mathrm{C}$.

Alloying and modification of Al-Si-based alloys with rare earth metals (REM) are one of the most effective ways to increase their properties through the implementation of a full range of mechanisms of influence - the formation of precipitates, grain refinement, structure modification, and obtaining a high-temperature stability strengthening phases $[5,31,32]$. These elements have almost zero solubility in aluminum and are able to form dispersed stable high-temperature aluminides with low diffusion activity.

Among REM modifiers for silumins and other cast aluminum alloys, the most attention is paid to cerium, lanthanum, and erbium [3, 33-35]. The first two elements are characterized as structure modifiers, especially for eutectics. Erbium, in turn, is a valuable hardener that can form aluminide phases with an FCC lattice similar to scandium - one of the most valuable modifier for aluminum alloys.

Scandium is the first transition metal and also belongs to the rare earth elements. To increase the mechanical properties of deformable aluminum alloys use these element due to a very effective strengthening effect, which emits small coherent precipitates of $\mathrm{Al}_{3} \mathrm{Sc}$ in aluminum matrix. To strengthen aluminum alloys as an alternative to copper scandium can also be used to increase corrosion properties [3, 36, 37].

Uses of scandium for cast aluminum alloys have been and remains largely limited due to low economic feasibility. However, studies of the interaction of this element with the components of silumins, in particular with silicon, have been conducted for a long time. In [38], the negative effect of silicon, even at its concentration at the level of $0.2-1 \%$ wt., due to the formation of rougher $\mathrm{Al}_{3} \mathrm{Sc}$ intermetallics $\mathrm{AISc}_{2} \mathrm{Si}_{2}$. The hardness of scandium-doped alloys increased with increasing silicon content in the cast state, but after aging such alloys are losing their hardness compared to silicon-free. In the presence of silicon, the grain boundaries were depleted of scandium under prolonged temperature loading, which indicates a decrease in their creep resistance.

Simultaneous addition of titanium, zirconium and hafnium is also used to ensure the effective use of scandium as a modifier of aluminum alloys. This technique provides the formation of thermally stable phases of $\mathrm{Al}_{3}(\mathrm{Sc}, \mathrm{Zr} / \mathrm{Ti} / \mathrm{Hf})$, including - with a two-layer "coreshell" structure with a favorable structure of the $\mathrm{L}_{2}$-type [39-41].

The addition of molybdenum and manganese together with scandium contributes to a significant reduction in the rate of coagulation of precipitates mainly due to the binding of silicon [42]. In this case, in the vast majority of studies, the silicon content in alloys does not exceed $1 \%$ wt., which complicates the understanding of the role of scandium as a modifier of Al-Si alloys to improve their performance.

Simultaneous addition of scandium and REM to aluminum alloys in some cases allows to replace part of scandium and thus reduce the cost of modification and the same time to increase the high temperature stability of the formed reinforcing precipitates. The solubility of $\mathrm{REM}$ in $\mathrm{Al}_{3} \mathrm{Sc}$ intermetallic with $\mathrm{L}_{2}$ lattice increases with increasing the atomic mass. Thus, the solubility of $\mathrm{La}$ and $\mathrm{Ce}$ is $-0.1, \mathrm{Nd}$, Sm and $\mathrm{Eu}-0.3$, and $\mathrm{Yb}$ and $\mathrm{Lu}-7.9-20 \%$ at. The dependence of hardness on the atomic mass of the third component is inversely proportional to this [43].

For silicon-reach alloys, some REM are able to create complex phases, similar to AISc${ }_{2} \mathrm{Si}_{2}$. Eu modifies $\mathrm{Si}$ into a coral-like structure while $\mathrm{Yb}$ does not. Atom probe tomography shows that $\mathrm{Eu}$ is present within the Si phase in the form of ternary compound $\mathrm{Al}_{2} \mathrm{Si}_{2} \mathrm{Eu}$ clusters, while $\mathrm{Yb}$ is absent in the Si phase. This indicates that the presence of ternary compound clusters within $\mathrm{Si}$ is a necessary condition for the formation of a coral-like structure [44]. Somehow, there is no widely researched data about complex Al-Sc-REM-Si compounds, formed in overviewed alloys, but it's obvious, that different REE may cause different influence on structural and phase condition of silumins, modified by Sc. 
Despite many years of research into ways to improve the performance of industrial creep-resistant $\mathrm{Al}-\mathrm{Si}$-based foundry alloys through the introduction of various microadditives, many issues such as complex modifications of transitional, refractory and rare earth elements remain unexplored, although the potential of such techniques is undoubtedly high.

\section{References}

1 Birol Y. Grain refinement and modification of Al-Si foundry alloys with B and Sr additions. Materials science and technology. 2014. Vol. 30. № 10. pp. 1154-1161

2 Hanna M.D., Shu-Zu Lu and A. Hellawell. Modification in the aluminum silicon system. Met. Transact. 1984. Vol. 15A. № 3. P. 459-469.

3 Knipling K.E, Dunand D.C., Seidman D. E. Criteria for developing castable, creep-resistant aluminum-based alloys. A review. International Journal of Materials Research. 2006. № 97(3), pp. 246-265.

$4 \mathrm{Wu} \mathrm{H}$. et al. Effect of Er additions on the precipitation strengthening of $\mathrm{Al}-\mathrm{Hf}$ alloys. Scripta Materialia. 2014. Vol. 87. pp. 5-8.

5 Rana R. S., Rajesh Purohit, Das S. Reviews on the Influences of Alloying elements on the Microstructure and Mechanical Properties of Aluminum Alloys and Aluminum Alloy Composites. International Journal of Scientific and Research Publications. 2012. Vol. 2, Issue 6. pp. 1-7.

6 Hurtalova L., Tillova E., Chalupova M. The structure analysis of secondary (recycled) AISi9Cu3 cast alloy with and without heat treatment. Engineering transactions. 2013. Vol. 63 (3). pp. 197-218.

7 Stadler F. et al. Effect of main alloying elements on strength of Al-Si foundry alloys at elevated temperatures. International Journal of Cast Metals Research. 2012. Vol 25. № 4. pp. 245-224.

8 Molina R., Amalberto P., Rosso M. Mechanical characterization of aluminium alloys for high temperature applications. Part 1: Al-Si-Cu alloys. Metallurgical science and technology. 2011. Vol. 29-1. pp. 5-15.

9 Belov N.A, Alabin A.N, Eskin D.G., Istomin-Kastrovskiy V.V. Optimization of Hardening of Al-Zr-Sc Casting Alloys. Journal of Material Science. 2006. № 41. pp. 5890-5899.

10 Kumar K. S. Ternary intermetallics in aluminium refractory-metal $X$ systems $(X=V, C r, M n$, $\mathrm{Fe}, \mathrm{Co}, \mathrm{Ni}, \mathrm{Cu}, \mathrm{Zn}$ ). Intermetallic Materials Review. 1990. № 35 (6). pp. 293-327.

11 Kumar K.S. Advanced intermetallics // Physical metallurgy and processing of intermetallic compounds. - 1996. - P. 392-440.

12 Shaha S.K., Czerwinski F., KaspzakW., Friedman J., Chen D.L. Microstructure and mechanical properties of Al-Si cast alloy with additions of Zr-V-Ti. Materials \& Design. 2015. Vol. 83. pp. 801-812.

13 Mahmudi R., Sepehrband P., Ghasemi H.M. Improved properties of A319 aluminum casting alloy modified with Zr. 2006. Materials Letters. Vol. 60 pp. 2606-2610.

14 Samuel E. et. al. Effect of grain refiner on the tensile and impact properties of $\mathrm{Al}-\mathrm{Si}-\mathrm{Mg}$ cast alloys. 2014. Materials \& Design. Vol. 56. pp. 468-479.

15 KasprzakW., Amirkhiz B.S., Niewczas M., Structure and properties of cast Al-Si based alloy with $\mathrm{Zr}-\mathrm{V}-\mathrm{Ti}$ additions and its evaluation of high temperature performance. 2014. Journal of Alloys and Compounds. Vol. 595. pp. 67-79.

16 Pisarek B.P., Rapiejko C., Szymczak T., Pacyniak T. Effect of Alloy Additions on the Structure and Mechanical Properties of the AlSi7Mg0.3 Alloy. 2017. Archives of foundry engineering. Vol. 17, №1. pp. 137-142. 
17 Pietrowski S., Szymczak T., Siemińska-Jankowska B., Jankowski A. Selected characteristic of silumins with additives of $\mathrm{Ni}, \mathrm{Cu}, \mathrm{Cr}, \mathrm{Mo}, \mathrm{W}$ and V. 2010. Archives of Foundry Engineering. Vol. 10, №1. pp. 107-126.

18 Bolibruchova D., Zihalova M.. Vanadium influence on iron based intermetallic phases in AISi6Cu4 alloy. 2014. Archives of metallurgy and materials. № 3. pp. 837-841.

19 Voron M. M., Matviets Ye. O., Antonevitch Ya. K., Kushnir K. S. Vanadium edition influence on the structural and phase parameters of Al-Si-Cu Alloys. Casting Processes. 2019. № 6 (138). pp.53-59.

20 Ahmad R. The Effect of Chromium Addition on Fluidity, Microstructure and Mechanical Properties of Aluminum Im6 cast Alloy. 2018. International Journal of materials science research. Vol. 1(1). pp. 32-35.

21 Timelli G., Bonollo $\mathrm{F}$. The influence of $\mathrm{Cr}$ content on the microstructure and mechanical properties of AlSi9Cu3(Fe) die-casting alloys. Materials Science and Engineering. A. 2010. № 528. pp. 273-282.

22 Timelli G., Fabrizi A., Capuzzi S., Bonollo F., Ferraro S. The role of $\mathrm{Cr}$ additions and Fe-rich compounds on microstructural features and impact toughness of AISi9Cu3 (Fe) diecasting alloys. Materials Science and Engineering: A. 2014. № 603 pp. 58-68.

23 Mahta M., Emamy M., Cao, X., Campbell J., Overview of $\beta-\mathrm{Al}_{5} \mathrm{FeSi}$ phase in Al-Si alloys. Materials Science Research Trends. 2008. pp. 251-271,

24 Serák, J., Vojktéch, D. Influence of (AISIFeMnCr) intermetallic phases on the casting properties of AlSi9Cu2FeMnCr alloys. Aluminium. 2002. Vol. 78. pp. 384-387.

25 Zamani M., Toschi S., Morri A., Ceschini L., Seifeddine S. Effect of Mo Addition on Room and High Temperature Tensile Behavior of Al-Si-Cu-Mg Alloy in As-Cast and Heat-Treated Conditions. Advanced Materials Research. 2019. Vol. 1155. pp. 71-79.

26 Mori A., Ceschini L., Messieri S., Cerri E., Toschi S. Mo Addition to the A354 (Al-Si-Cu$\mathrm{Mg}$ ) Casting Alloy: Effects on Microstructure and Mechanical Properties at Room and High Temperature. Metals. 2018. № 8. pp. 393-411.

27 Farkoosh, A.R.; Chen, X.G.; Pekguleryuz, M. Dispersoid strengthening of a high temperature Al-Si-Cu-Mg alloy via Mo addition. Mater. Sci. Eng. A. 2015. Vol. 620. pp. 181-189.

28 Zhi-Hong J., Hui-Lan H., Xue-Li W., Yuan X., Qing L. Hafnium in Alluminum alloys: A Review. Acta Metall. Sin. 2016. Vol. 29, № 2. pp. 105-119.

29 Eigenfeld K. et al. New developments in heat resistant aluminum casting materials. Casting plant and Technology International. 2004, vol. 4. pp. 4-9.

30 Hallem H., Forbord B., Marthinsen K. An investigation of dilute Al-Hf and Al-Hf-Si alloys. Materials Science and Engineering A. 2004. Vol. 387-389. pp. 940-943.

31 Barlat F., Liu J. Precipitate-induced anisotropy in binary A1-Cu alloys. Materials Science and Engineering A. 1998. Vol. 257. pp. 47-61.

32 Xiao D. H., Wang J. N., Ding D. Y., Yang H. L. Effect of rare earth Ce addition on the microstructure and mechanical properties of an Al-Cu-MgAg alloy. Journal of Alloys and Compounds. 2003. Vol. 352. pp. 84-88.

33 Hosseinifar M., Malakhov D. V. Effect of Ce and La on microstructure and properties of a 6xxx series type aluminum alloy. Journal of Materials Science. 2008. vol. 43, №. 22. pp. 7157-7164.

34 Nogita K., McDonald S. D., Dahle A. K. Eutectic modification of Al-Si alloys with rare earth metals. Materials Transactions. 2004. vol. 45, № 2. pp. 323-326.

35 Pourbahari B., Emamy M., Lotfpour M., Allameh S. H. Effects of La intermetallics on the structure and tensile properties of thin section gravity die-cast A357 Al alloy. Proceedings of the International Conference on Chemical, Metallurgy and Environmental Engineering (ICMAEE '15). Istanbul, Turkey, June 2015. pp. 296-303.

36 Langdon T.G. Twenty-five years of ultrafine-grained materials: achieving exceptional properties through grain refinement. Acta Materialia. 2013. Vol. 61. pp. 7035-7059. 
37 Cavanaugh M., Birbilis N., Buchheit R., Bovard F., Investigating localized corrosion susceptibility arising from Sc containing intermetallic Al3Sc in high strength Al-alloys. Scripta Materialia. 2007. Vol 56. pp. 995-998.

38 Royset J. An investigation of dilute Al-Si-Sc alloys. Materials science forum. 2002. Vols. 396-402. pp. 619-624.

39 Avtokratova E. et al. Microstructural evolution in $\mathrm{Al}-\mathrm{Mg}-\mathrm{Sc}-\mathrm{Zr}$ alloy during severe plastic deformation and annealing. Journal of Alloys and Compounds. 2016. Vol. 673. pp. 182-194.

$40 \mathrm{Nasim} \mathrm{W}$. et al. Structure and growth of core-shell nanoprecipitates in $\mathrm{Al}-\mathrm{Er}-\mathrm{Sc}-\mathrm{Zr}-\mathrm{V}-\mathrm{Si}$ high-temperature alloys. Journal of materials science. 2019. Vol. 54. pp. 1857-1871.

41 Booth-Morrison C., Mao Z., Diaz M., Dunand D.C., Wolverton C., Seidman D.N. Role of silicon in accelerating the nucleation of $\mathrm{Al}(\mathrm{Sc}, \mathrm{Zr})$ precipitates in dilute $\mathrm{Al}-\mathrm{Sc}-\mathrm{Zr}$ alloys. Acta Materialia. 2012. Vol. 60. pp. 4740-4752.

42 De Luca A., Shu S., Seidman D. N. Effect of microadditions of Mn and Mo on dual L1 $1_{2}$ - and $\alpha$-precipitation in a dilute Al-Zr-Sc-Er-Si alloy. Materials Characterization. 2020. Vol. 169: 110585.

43 Harada Y., Dundnd D. C. Miicrostructure of $\mathrm{Al}_{3} \mathrm{Sc}$ with ternary rare-earth additions. Intermetallics. 2009. Vol. 17. pp. 17-24.

44 Barrirero, J., Pauly, C., Engstler, M. et al. Eutectic modification by ternary compound cluster formation in Al-Si alloys. Scientific reports. 2019. Vol. 9, 5506. https://doi.org/10.1038/ s41598-019-41919-2

М. М. Ворон, канд. техн.наук, старш. наук. співроб.;

e-masl:mihail.voron@gmail.com

М. А. Фон Прусс, аспірант, пров. інженер

О. Є. Биба, інженер

Фізико-технологічний інститут металів та сплавів НАН України (Київ, Україна)

\section{МІКРОЛЕГУВАННЯ ТА МОДИФІКАЦІЯ ЛИТИХ АЛЮМІНІЄВИХ СПЛАВІВ ДЛЯ ПІДВИЩЕННЯ ЇХ ЕКСПЛУАТАЦІЙНИХ ВЛАСТИВОСТЕЙ ПРИ ПІДВИЩЕНИХ ТЕМПЕРАТУРАХ. ОГЛЯД.}

Робота присвячена аналізу впливу найбільш ефективних мікролегуючих добавок та модифікаторів для підвищення механічних властивостей силумінів при їх експлуатації за умов підвищених температур. Показано, що ливарні алюмінієві сплави на основі системи Al-Si відносяться до ряду дешевих та широковживаних жароміцних алюмінієвих сплавів, проте їх рівень механічних властивостей $є$ доволі низьким, а межі температур експлуатації здебільшого визначаються величиною до $250^{\circ} \mathrm{C}$. Для підвищення рівня експлуатаційних властивостей даного типу сплавів широко застосовують модифікування та мікролегування. Останні роки все більш ефективним вважається комплексне багатокомпонентне модифікування силумінів такими елементами, як хром, марганець, нікель, кобальт, титан, цирконій та ванадій, які дозволяють реалізувати багатофакторний вплив на структурно-фазовий стан сплавів - реалізацію зародкоутворюючого механізму, утворення стабільних дисперсоїдів, зміну морфології залізовмісних фаз, тощо. Попарне або потрійне додавання цих елементів сумарною кількістю до 0,25 \%мас. в багатьох випадках сприяє збільшенню ефективності від модифікування, порівняно з введенням одного елемента. Показано, що додавання ванадію, молібденута вольфраму сприяє підвищенню твердості та зниженню міцності сплавів в литому стані. При цьому, після гартування та двоступінчастого старіння, для сплавів з молібденом спостерігається підвищення межі плинності на 10 \% при збереженні рівня міцності. Гафній розглядається як перспективний зародкоутворюючий елемент, додавання якого також сприяє значному підвищенню опору рекристалізації. Його додавання до жароміцних алюмінієвих сплавів може забезпечити стабілізацію механічних властивостей до $400{ }^{\circ} \mathrm{C}$. При цьому 
необхідно забезпечити максимально можливе подрібнення інтерметалідів гафнію, особливо за наявності у сплаві кремнію.Модифікування алюмінієвих сплавів скандієм з додаванням титану, цирконію або гафнію сприяє утворенню дисперсоїдів Al ${ }_{3}(\mathrm{Sc}, \mathrm{Zr} / \mathrm{Ti} / \mathrm{Hf})$, з кубічною кристалічною ґраткою сприятливої симетрії L1 2 та стабільною шаруватою структурою “core-shell”. При цьому вміст кремнію в сплаві має бути мінімальним через утворення шкідливих силіцидів. Додавання рідкоземельних металів чинить подібний ефект, проте без формування шаруватих структур. При цьому, РЗМ можуть утворювати силіциди, а можуть модифікувати евтектичний або первинний кремній. В обох випадках, додавання перехідних металів або РЗМ, одночасно з модифікуванням сплавів скандієм, підвищує високотемпературну стабільність механічних властивостей ливарних алюмінієвих сплавів на основі системи Al-Si через формування менш активних та дифузійнорухомих зміцнюючи дисперсних фаз.

Ключові слова: ливарні алюмінієві сплави, силуміни, комплексне модифікування, перехідні метали, рідкоземельні метали. 